\title{
Microbiological and micro-computed tomography analysis of natal teeth: a case report
}

Análise microbiológica e por micro-tomografia computadorizada de dente natal: Relato de caso Análisis microbiológico y microtomografía computarizada del diente nativo: Informe de caso Alice Corrêa SILVA-SOUSA ${ }^{1}$

Yara Teresinha Corrêa SILVA-SOUSA ${ }^{2}$ André PITONDO-SILVA ${ }^{3}$ Rafael NAKAMURA-SILVA 4 Nathalia Cristina TAVELLA-SILVA ${ }^{5}$ Marcelle DANELON ${ }^{6}$

${ }^{1}$ School of Dentistry, University of Ribeirão Preto (UNAERP), RibeirãoPreto, SP, Brazil; Student (Doctoral Degree) of Department of Restorative Dentistry, School of Dentistry of Ribeirão Preto, University of São Paulo (FORP-USP), Ribeirão Preto, SP, Brazil

${ }^{2}$ Titular Professor, School of Dentistry, University of Ribeirão Preto (UNAERP), 14096-900 Ribeirão Preto - SP, Brazil

${ }^{3}$ Associate Professor, School of Dentistry, University of Ribeirão Preto (UNAERP), 14096-900 Ribeirão Preto - SP, Brazil

${ }^{4}$ Ph.D Student of Graduate Program in Environmental Technology, University of Ribeirão Preto (UNAERP), Ribeirão Preto, SP, Brazil ${ }^{5}$ Student, School of Dentistry, University of Ribeirão Preto (UNAERP), 14096-900 Ribeirão Preto - SP, Brazil

${ }^{6}$ Department of Preventive and Restorative Dentistry, São Paulo State University (UNESP), School of Dentistry, Araçatuba-SP, Brazil, School of Dentistry, University of Ribeirão Preto (UNAERP), 14096-900 Ribeirão Preto - SP, Brazil

\section{Abstract}

The aim of this study was to report a clinical case of a natal teeth found in a 1-day-old newborn, its clinical implications and proper management. The female patient was referred by a pediatrician who contacted the University of Ribeirão Preto Pediatric Dentistry Clinic (UNAERP, Ribeirão Preto, Brazil), informing that the patient with 40 hours of life, still in the maternity ward, had a foreign body in the oral cavity since birth, which was bothering the mother at the time of breastfeeding. At clinical examination, the presence of a natal teeth with grade 3 mobility was observed. After one month of life, it was possible to perform a radiographic examination, which resulted in the definitive diagnosis of the Christmas tooth, and the proposed treatment was the surgical removal of the dental element and subsequent follow-up. Prior to surgical removal, the biofilm present on the coronary surface was aseptically collected for microbiological analysis consisting of isolating the bacteria in different culture media and identifying them by $16 \mathrm{~S}$ rRNA sequencing. The extracted tooth was scanned in high-resolution microtomography, reconstructed, and qualitatively analyzed. Microbiological analyses showed the presence of two bacterial species Streptococcus salivarius and Staphylococcus hominis, both species considered commensal, being part of the oral microbiota. The knowledge of this anomaly and the training of dentists to perform an accurate diagnosis, as well as the importance of multidisciplinary work, are of extreme relevance.

Descriptors: Natal Teeth; Tomography Scanners, X-Ray Computed; Oral Health; Pediatric Dentistry.

\section{Resumo}

O objetivo deste estudo foi relatar um caso clínico de dente natal encontrado em um recém-nascido com 1 dia de vida, suas implicações clínicas e manejo adequado. A paciente, do sexo feminino, foi encaminhada por um pediatra que entrou em contato com a Clínica de de Odontopediatria da Universidade de Ribeirão Preto (UNAERP, Ribeirão Preto, Brasil ), informando que a paciente com 40 horas de vida, ainda na maternidade, apresentava um corpo estranho na cavidade bucal, desde o nascimento, que estava incomodando a mãe no momento da amamentação. Ao exame clínico, foi observada a presença de um dente Natal, com mobilidade grau 3. Com um mês de vida, foi possível realizar exame radiográfico, que resultou no diagnóstico de dente decíduo natal e o tratamento proposto foi a remoção cirúrgica do elemento dentário e posterior acompanhamento. Previamente à remoção cirúrgica, o biofilme presente na superfície coronária foi coletado assepticamente para análises microbiológicas que consistiam em isolar as bactérias em diferentes meios de cultura e identificá-las por sequenciamento de 16S rRNA. O dente extraído foi escaneado em microtomografia de alta resolução e reconstruído e analisado qualitativamente. As análises microbiológicas mostraram a presença de duas espécies bacterianas Streptococcus salivarius e Staphylococcus hominis, ambas consideradas comensais, fazendo parte da microbiota oral. O conhecimento desta anomalia e o treinamento de cirurgiões-dentistas para realizar um diagnóstico preciso, assim como a importância do trabalho multidisciplinar, são de extrema relevância.

Descritores: Dentes Natais; Tomógrafos Computadorizados; Saúde Bucal; Odontopediatria.

\section{Resumen}

El objetivo de este estudio era informar sobre un caso clínico de un diente natural encontrado en un recién nacido de un día, sus implicaciones clínicas y su manejo adecuado. La paciente fue remitida por un pediatra que se puso en contacto con la Clínica de Odontología Pediátrica de la Universidad de Ribeirão Preto (UNAERP, Ribeirão Preto, Brasil), informando de que la paciente con 40 horas de vida, todavía en la sala de maternidad, tenía un cuerpo extraño en la cavidad bucal desde el nacimiento, que estaba molestando a la madre en el momento de la lactancia. En el examen clínico, se observó la presencia de un diente de Navidad con movilidad de grado 3. Después de un mes de vida, fue posible realizar un examen radiográfico, que resultó en el diagnóstico definitivo del diente de Navidad, y el tratamiento propuesto fue la extracción quirúrgica del elemento dental y su posterior seguimiento. Antes de la extirpación quirúrgica, el biofilm presente en la superficie coronaria se recogía asépticamente para un análisis microbiológico que consistía en aislar las bacterias en diferentes medios de cultivo e identificarlas mediante la secuenciación del ARNr 16S. El diente extraído fue escaneado en una microtomografía de alta resolución y reconstruido y analizado cualitativamente. Los análisis microbiológicos demostraron la presencia de dos especies de bacterias, Streptococcus salivarius y Staphylococcus hominis, ambas especies consideradas comensales, que forman parte de la microbiota oral. El conocimiento de esta anomalía y la formación de los dentistas para realizar un diagnóstico preciso, así como la importancia del trabajo multidisciplinario, son de extrema relevancia.

Descriptores: Dientes Neonatales; Tomógrafos Computarizados por Rayos X; Salud Bucal; Odontologia Pediátrica.

INTRODUCTION

Early attention to the baby is extremely important, as during infancy the oral cavity may present numerous occurrences that constitute physiological responses, developmental changes and even pathogens ${ }^{1,2}$. Teeth eruption is a physiological process that begins around six 
months of age, the lower central incisors being the first teeth to erupt in the oral cavity ${ }^{1,3,4}$. However, there are cases in which the baby is born with erupted teeth or the eruption occurs in the first month of life, being named respectively natal and neonatal teeth ${ }^{1,5}$.

Natal teeth may present normal sizes and shapes, but most of the time microdontia, conoid teeth, opaque yellow-brown discoloration, hypoplastic, with deficiency or absence of root development resulting in dental mobility, causing discomfort or difficulty to the baby during breastfeeding, the risk of swallowing or aspiration of the teeth in addition to causing trauma to the nipple of the maternal breast or ulcerations in the belly of the tongue of the newborn ${ }^{6}$.

The diagnosis should be made by intraoral clinical examination, radiography, medical history and family pattern. There are similarities between the Epstein's Pearls and Gingival Cyst as the shapes and staining, however, what differs each one is the size and its location, which may confuse the professional due to the fact that the teeth erupt in the alveolar border $^{6}$. Before diagnosis, the treatment management to be applied to natal teeth of the normal series is to preserve the dental element by softening the incisal margins in order not to injure the breast during breast-feeding, in addition to preventing the lesion of Riga-Fede in the tongue of the newborn, but in cases of high mobility or this dental element that is supernumerary, exodontia is indicated due to the absence of bone insertion, risk of dislocation during breast-feeding and consequent aspiration, resulting in risk to the health of the baby $^{7}$. These procedures should be followed after the first 10 days of birth due to vitamin $\mathrm{K}$ deficiency in the newborn, preventing excessive bleeding ${ }^{4,8}$.

The aim of the present study was to report a clinical case of a natal teeth found in a newborn with 40 hours of life, their clinical implications and adequate management.

\section{CLINICAL CASE}

The responsible for the patients have previously authorized, through the informed consent form, the treatment performed, the documentation and subsequent publication. The patient, female, was referred by a pediatrician who contacted the Clinic School of Pediatric Dentistry, in University of Ribeirão Preto (UNAERP, Brazil) informing that the patient with 40 hours of life, still in the maternity ward, had something in the oral cavity, since birth (Figure 1A), that was bothering the mother at the time of breastfeeding.
On intraoral examination, the presence of a natal teeth without root implantation was observed. According to the clinical and radiographic analysis (Figure 1B and Figure 1C), the treatment plan chosen was the surgical removal of the element and follow-up of the case.

After the preoperative care, the biofilm present on the coronary surface was aseptically collected in duplicate, with the aid of sterile disposable microbiological loops and transferred to Brain Heart Infusion (BHI) and Thioglycolate broth culture media (Oxoid Ltd., Basingstoke, UK), for conservation of possible anaerobic and aerobic bacteria, respectively and subsequent microbiological analyzes. Then, topical anesthesia of the area was performed with and then local terminal anesthesia was infiltrated with cytocaine $3 \%$. After the syndesmotomy, the element was exodonted using only sterile gauze and hollemback 01 infant. After the exodonty the mother breastfed the baby. Postoperative guidance was given to those responsible for the patient. The follow-up of seven days after surgery was done by clinical examination and showed excellent healing (Figure 1F).

Next extraction, the tooth was scanned in a SkyScan 1176 Microtomograph (Bruker, Kontich, Belgium) from the Research Laboratory of the of the Graduate Program in University of Ribeirão Preto (Figure 1D and Figure 1E). Reconstructed and analyzed using NRecon v. 1.6.9.18 and CTvox v.1.14.4 software. As a control, a deciduous tooth from the normal series was scanned and reconstructed with similar parameters.

For microbiological analyses, $10 \mu \mathrm{L}$ of the medium with the biofilm was inoculated in duplicate in Petri dishes containing three different solid culture media: BHI, Blood Agar and MacConkey. BHI and Blood Agar (Oxoid Ltd., Basingstoke, UK), are rich media that allow the growth of nutritionally demanding bacteria and also those that need blood in their metabolism, respectively. Thereafter, a set of three different plates were incubated in the presence of oxygen and or another set in 10\% $\mathrm{CO}_{2}$, to allow the growth of aerobic and anaerobic bacteria respectively. The plates were kept at $37^{\circ} \mathrm{C}$ for up to 48 hours. Only the $\mathrm{BHI}$ and Blood Agar plates incubated in aerobic conditions showed bacterial growth of two different morphological types. The genomic DNA from the two isolates was extracted using a QIAamp1 DNA Mini Kit (QIAGEN, Hilden, Germany) according to the manufacturer's instructions. The bacterial isolates were identified by amplification and subsequent 
sequencing of the 16S rRNA according to Weisburg et al. ${ }^{9}$. Two Gram-positive bacterial species have been identified: Streptococcus salivarius and Staphylococcus hominis.

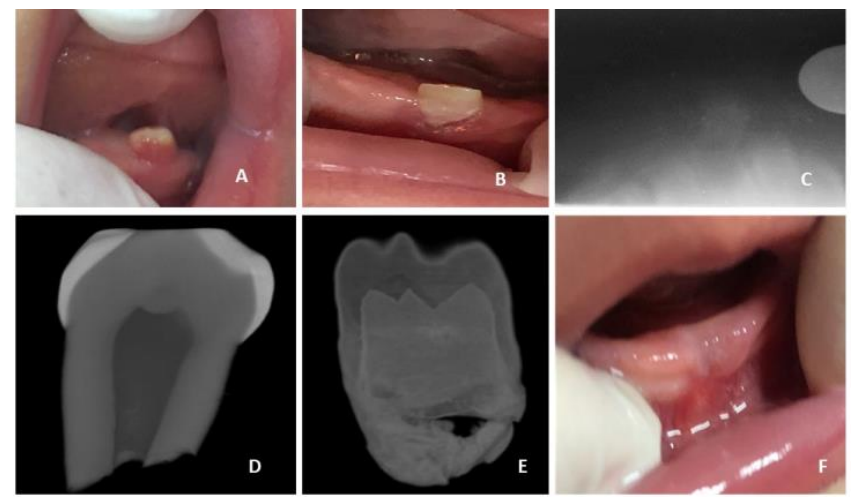

Figure 1: (A) Initial clinical examination - 40 hours of life; (B-C) Clinical and radiographic examination - 30 days of life; Threedimensional model of (D) normal series deciduous teeth (control) and $(E)$ extracted natal teeth; (F) Postoperative seven days.

DISCUSSION

Studies have reported that the vast majority of natal teeth are belonging to the normal series and not supernumerary ${ }^{10,11}$, as observed in our study. Although the exact cause of this condition is still unknown, many etiological theories have been postulated. Among the clinical characteristics the natal teeth are small, or of normal size, conical, or of normal shape. They may reveal an immature appearance with enamel hypoplasia and small root formation. Among the possible complications that are associated with natal teeth are dental aspiration, sublingual ulceration, and difficulty with breastfeeding. In our study, after clinical examination, the presence of a grade 3 mobile natal teeth and ulceration of the mother's nipple is also a cause for concern. Therefore the treatment proposed was the surgical removal of the dental element and subsequent follow-up. Furthermore, In the study by Moura et al. ${ }^{12}$ the authors reported that two of the 23 cases of native teeth had difficulty breastfeeding. In our study, as reported by the mother, there was also discomfort during breastfeeding.

The extraction of natal teeth can be justified on the basis of a series of clinical analyses. Implications, such as hypermobility, as well as when they present as shell-like enamel structures that, if left, can lead to infection, which can result in systemic complications. In also, the use of micro-CT analysis provides a greater understanding of teeth mineral density, thickness and volume of native teeth. This, in turn, allows clinicians to be better informed and thus avoid leaving the remaining cells to evolve into a root-like structure without a crown ${ }^{13}$. The qualitative analysis of the three-dimensional images, made by means of Computerized Microtomography, we could observe a difference in the morphology of the deciduous teeth to this natal teeth, a wider root canal at natal teeth, as well as a small layer of enamel, which is much thicker in the deciduous teeth.

Recent studies have been demonstrating that the mode of birth does not have a great influence on the infant oral microbiota after four weeks of birth. Changes in the diversity and composition of the newborn's microbiota are most visible at six months and again around one year of age, when both teeth begin to emerge, and weaning and introduction of food into the child's diet begins ${ }^{14}$. Tuominen et al. ${ }^{15}$ suggest that the formation of the oral microbiota may begin in the uterus before birth, probably influenced by the microorganisms present in the placenta and appears not to be intimately modulated by the birth canal microbiota, regardless of the mode of delivery. This fact indicates that the microbiota of the neonatal oral cavity may have a prenatal origin that precedes exposure to the birth canal. In our study, we found in the teeth of the newborn the presence of two bacterial species $S$. salivarius and $S$. hominis, both species are considered commensal, being part of the human microbiota. $S$. salivarius is particularly common in the oral microbiota $^{16}$. S. salivarius is one of the first species to colonize the oral cavity of newborns.

Some studies estimate that in a few hours, this species will begin to colonize the newborn's oral mucosa. In addition, this species plays an important role in the human oral microbiota, since it produces bacteriocins that can inhibit the presence of other potentially pathogenic bacterial species ${ }^{16}$. Similar to $S$. salivarius, $S$. hominis also produces a potent bacteriocin that is called hominicin, which has activity against clinically relevant strains of Staphylococcus aureus, including MRSA (methicillin-resistant S. aureus) and VISA (intermediate with vancomycin $S$. aureus) ${ }^{17}$. S. hominis is very common in the human skin microbiota and is considered harmless, however, it can cause disease in immunocompromised individuals and represents the third most common organism recoverable from the blood of immunocompromised patients which may have a high prevalence of methicillin resistance and resistance to other antibiotics ${ }^{18}$. In this study, we believe that both species found in the newborn's tooth biofilm may have been acquired from the maternal microbiota. Furthermore, like $S$. salivarius, $S$. hominis was considered a commensal bacterium, since the patient was totally healthy. 


\section{CONCLUSION}

It was possible to conclude that, despite a certain rarity, the knowledge of this anomaly and the training of dentists to make an accurate diagnosis is of extreme relevance. Besides emphasizing the importance of multidisciplinary work.

\section{REFERENCES}

1. Agrawal NK, Khatry SK, LeClerq SC, Katz J, Mullany LC. Incidence of Natal Teeth in Sarlahi District of Nepal. J Nepal Health Res Counc. 2019 Apr 28;17(1):100-2.

2. Kalra $N$, Tyagi $R$, Khatri $A$, Kumar $S, M m A$, Khandelwal D. Neonatal molar in a child with Langerhan cell histiocytosis. J Indian Soc Pedod Prev Dent. 2019;37(1):107-9.

3. Kana A, Markou L, Arhakis A, Kotsanos N. Natal and neonatal teeth: a systematic review of prevalence and management. Eur J Paediatr Dent. 2013;14(1):27-32.

4. Rocha JG, Sarmento LC, Gomes AMM, Valle MAS, Dadalto ECV. Natal tooth in preterm newborn: a case report. RGO - Rev Gaúcha Odontol. 2017;65(2):156-60.

5. Jamani NA, Ardini YD, Harun NA. Neonatal tooth with Riga-Fide disease affecting breastfeeding: a case report. Int Breastfeed J. 2018;13:35.

6. Kérourédan $O$, Smirani $R$, Thébaud NB, Devillard R. Diagnosis and Management of Natal and Neonatal Teeth: Case Report of Three Newborns. J Dent Child (Chic). 2018;85(2):79-82.

7. Bulut G, Bulut H, Ortac R. A comprehensive survey of natal and neonatal teeth in newborns. Niger J Clin Pract. 2019;22(11):1489-94.

8. Management Considerations for Pediatric Oral Surgery and Oral Pathology. Pediatr Dent. 2018;40(6):373-382.

9. Weisburg WG, Barns SM, Pelletier DA, Lane DJ. 16S ribosomal DNA amplification for phylogenetic study. J Bacteriol. 1991;173(2):697-703.

10. Samuel SS, Ross BJ, Rebekah G, Koshy S. Natal and Neonatal Teeth: A Tertiary Care Experience. Contemp Clin Dent. 2018;9(2): 218-22.

11. Mendes Gouvêa CC, Danelon M, Cunha RF. Dente natal: diagnóstico e conduta clínica. Relato de caso. Arch Health Invest 2016; 5(Spec Iss 1):216.

12. Moura LF, Moura MS, Lima MD, Lima CC, Dantas-Neta NB, Lopes TS. Natal and neonatal teeth: a review of 23 cases. J Dent Child (Chic). 2014;81(2):107-11.

13. Park JS, Patel J, Seewoo BJ, King NM, Anthonappa RP. Literature review and microcomputed tomography analysis of natal teeth: $\mathrm{A}$ pilot study. J Investig Clin Dent. 2019;10(4):e12466.
14. Hurley E, Mullins D, Barrett MP, O'Shea CA, Kinirons M, Ryan CA, Stanton C, Whelton $\mathrm{H}$, Harris HMB, O'Toole PW. The microbiota of the mother at birth and its influence on the emerging infant oral microbiota from birth to 1 year of age: a cohort study. J Oral Microbiol. 2019;11(1):1599652.

15. Tuominen H, Collado MC, Rautava J, Syrjänen S, Rautava S. Composition and maternal origin of the neonatal oral cavity microbiota. J Oral Microbiol. 2019;11(1):1663084.

16. Fantinato V, Camargo HR, Sousa ALOP de. Probiotics study with Streptococcus salivarius and its ability to produce bacteriocins and adherence to KB cells. Rev Odontol da UNESP. 2019;48:e20190029.

17. Pauer $\mathrm{H}$, Glatthardt $\mathrm{T}$, Ferreira NV, Ferreira RBR, Antunes LCM. Bioactive Molecules of the Human Microbiome. In: Microbiome and Metabolome in Diagnosis, Therapy, and Other Strategic Applications. Elsevier; 2019:115-125.

18. Mendoza-Olazarán S, Morfin-Otero R, Rodríguez-Noriega E, Llaca-Díaz J, FloresTreviño S, González-González GM et al. Microbiological and molecular characterization of Staphylococcus hominis isolates from blood. PLoS One. 2013;8(4):e61161.

\section{CONFLICTS OF INTERESTS}

The authors declare no conflicts of interests.

\section{CORRESPONDING AUTHOR}

\author{
Marcelle Danelon \\ School of Dentistry, \\ University of Ribeirão Preto - UNAERP \\ Av Costábile Romano 2.201 \\ 14096-900 Ribeirão Preto - SP, Brazil \\ Tel. +551636036717 \\ Email: marcelledanelon@hotmail.com
}

Received 17/06/2020

Accepted 14/04/2021 